\title{
As relações entre pastoral e liturgia: a realidade latino-americana
}

\author{
Orientador: Prof. Abimar Oliveira de Moraes \\ Pesquisadora: Natasha Ribeiro \\ Fonte: $\mathrm{CNPq}$
}

\section{Introdução}

A prática pastoral é desenvolvida abundantemente na liturgia por conta do encargo de iniciar o fiel na Igreja através dos sacramentos e da vida comunitária. O Concílio do Vaticano II orienta um aperfeiçoamento da relação entre elas, a fim de que essa união protagonize novas experiências edificantes. Entretanto, a América Latina, atualmente, é alvo de várias críticas por conta do seu comprometimento pelas causas do povo. Muitos católicos, principalmente entre os jovens, acabam acusando a pastoral latino-americana de ter uma predileção pelas causas sociais do que pelas celebrações litúrgicas. Desconhecem, portanto, que não se pode separar a vida litúrgica do compromisso cristão em resgatar a dignidade humana diante de um mundo marcado pela desigualdade.

A liturgia não é apenas uma ação do homem, mas de Cristo na Igreja, uma relação que é eficaz. Cada ato litúrgico (batismo, eucaristia, demais sacramentos, ano litúrgico, ofício divino) tem um efeito específico, mas todos eles comunicam o mistério pascal e sua realização, por isso apesar do êxito ser diversos, Deus santifica sempre por meio de Cristo e do homem. Nas ações litúrgicas, a santificação que Deus faz na Igreja é o culto que a Igreja rende a Ele. Como "A glória de Deus é o homem vivo e a vida do homem consiste na visão de Deus", ${ }^{1}$ a liturgia é essa comunicação entre Deus e o ser humano, em um movimento em que o Pai vem ao nosso encontro para nos santificar e em resposta, nós nos voltamos para Ele para render graças.

A proposta da renovação litúrgica do Concílio do Vaticano II é fomentar a nossa participação ativa, através da propagação da natureza da litur-

\footnotetext{
${ }^{1}$ IRINEU DE LIÃO, Contra as heresias, IV, $20,7$.
} 
gia. Por isso, é importante que a liturgia seja sempre um pilar fundamental ao promover atividades para um aprofundamento da fé, porque ela "é o cume para o qual tende a ação da Igreja e, ao mesmo tempo, é a fonte donde emana toda a sua força". ${ }^{2}$ Entretanto, ainda não enxergamos que há um compromisso além do âmbito paroquial para se difundir em ações na sociedade, que a própria liturgia nos convida.

O Papa Bento XVI diz que "o amor pelos pobres é liturgia"3 ao elucidar o sentido de coleta no texto paulino (2Cor 9,12), e, dessa maneira, é necessária uma maior atenção em viver o espírito da reforma litúrgica, deixando com que o rito se comunique através de sua simplicidade. Assim, aqueles que possuem pouco se sentem dignos de estarem na presença da transcendência, já que notam que não é preciso uma ostentação para haver essa comunicação com Deus. Precisamos acolher e não humilhar quem não tem nada, reconhecer o outro como irmão e até honrá-lo, pois de nada adianta termos zelo pela casa do Senhor, se não zelarmos antes pelo templo mais precioso que é a pessoa humana.

\section{Objetivos}

A pesquisa consiste em mostrar à luz do Concílio do Vaticano II a amplitude da liturgia e pastoral, relacionando a "lex vivendi" com a "lex orandi", evocando a importância da formação litúrgica a todos nós batizados, para que haja uma participação consciente em todas as celebrações da Igreja.

\footnotetext{
${ }^{2} \mathrm{SC} 10$.

${ }^{3}$ Bento XVI, PP. Il Concilio di Gerusalemme e l'incidente di Antiochia. In: Bento XVI, PP. In cammino sotto la guida dell'apostolo Paolo nem bimilenário dela nascita. Città del Vaticano: Libreria Editrice Vaticana, 2009, p. 44 apud Boselli, O sentido espiritual da liturgia. Brasília: Edições CNBB, 2014, p. 171.
} 